\title{
Activity-Dependent Autocrine-Paracrine Activation of Neuronal P2Y Receptors
}

\author{
Eugenia Moskvina, Ursula Unterberger, and Stefan Boehm \\ Institute of Pharmacology, University of Vienna, A-1090 Vienna, Austria
}

Activation of $\mathrm{P} 2 \mathrm{Y}$ receptors by released nucleotides subserves important autocrine-paracrine functions in various non-neural tissues. To investigate how P2Y receptors are activated in a neuronal environment, we used PC12 cells in which nucleotides were found to elicit increases in inositol phosphates via $\mathrm{P}_{2} \mathrm{Y}_{2}$ and decreases in cAMP via $\mathrm{P}_{12} \mathrm{Y}_{12}$ receptors. Depolarization of PC12 cells raised inositol phosphates, and blockade of voltage-gated $\mathrm{Ca}^{2+}$ channels by $\mathrm{Cd}^{2+}$ or degradation of extracellular nucleotides by apyrase prevented this effect. In nondepolarized cells, apyrase did not affect inositol phosphates. Depolarization of PC12 cells also reduced the $\mathrm{A}_{2 \mathrm{~A}}$ receptormediated synthesis of cAMP. This effect was again prevented by $\mathrm{Cd}^{2+}$ or apyrase, but apyrase enhanced the synthesis of cAMP even in nondepolarized cells. Overexpression of rat $\mathrm{P}_{2} \mathrm{Y}_{2}$ receptors increased the nucleotide-dependent inositol phosphate accumulation and enhanced the effect of $\mathrm{K}^{+}$depolarization. Nevertheless, apyrase still failed to alter spontaneous inositol phosphate accumulation. Expression of rat $\mathrm{P} 2 \mathrm{Y}_{1}$ receptors, in contrast, led to huge increases in spontaneous inositol phosphate accumulation, which was reduced by a receptor antagonist or by apyrase. This increased synthesis of inositol phosphates could not be further enhanced by depolarization or receptor agonists, but when endogenous nucleotides were removed by superfusion, recombinant $\mathrm{P}_{2} \mathrm{Y}_{1}$ receptors could be activated to mediate an inhibition of M-type $\mathrm{K}^{+}$channels. These results indicate that nucleoside diphosphate-sensitive $\left(\mathrm{P}_{2} \mathrm{Y}_{12}\right.$ and $\left.\mathrm{P} 2 \mathrm{Y}_{1}\right)$ receptors are activated by spontaneous nucleotide release, whereas triphosphate-sensitive $\left(\mathrm{P}_{2} \mathrm{Y}_{2}\right)$ receptors require an excess of depolarizationevoked release to become activated.

Key words: P2Y receptors; inositol phosphates; cAMP; M-type $\mathrm{K}^{+}$current; PC12 cells; nucleotide release

\section{Introduction}

Extracellular nucleotides regulate various physiological functions, including smooth muscle contraction, platelet aggregation, mucociliary clearance, cell proliferation, and neurotransmission. These actions are mediated by ionotropic P2X and G-proteincoupled P2Y receptors (Ralevic and Burnstock, 1998). At least seven different mammalian $\mathrm{P} 2 \mathrm{Y}$ receptors have been identified: $\mathrm{P}_{1} \mathrm{Y}_{1}$ (Tokuyama et al., 1995), P2Y 12 (Hollopeter et al., 2001), and $\mathrm{P}_{2} \mathrm{Y}_{13}$ (Communi et al., 2001) are preferentially activated by ADP, whereas $\mathrm{P}_{2} \mathrm{Y}_{6}$ is activated by UDP (Nicholas et al., 1996). $\mathrm{P}_{11} \mathrm{Y}_{11}$ prefers ATP as an agonist (Communi et al., 1997), whereas $\mathrm{P}_{2} \mathrm{Y}_{2}$ (Lustig et al., 1993) and $\mathrm{P}_{4} \mathrm{Y}_{4}$ (Communi et al., 1995; Kennedy et al., 2000) are equally sensitive to ATP and UTP. In rats, $\mathrm{P}_{2} \mathrm{Y}_{1}, \mathrm{P}_{2} \mathrm{Y}_{2}, \mathrm{P}_{2} \mathrm{Y}_{4}, \mathrm{P}_{2} \mathrm{Y}_{6}$, and $\mathrm{P} 2 \mathrm{Y}_{12}$ have been detected (Ralevic and Burnstock, 1998; Hollopeter et al., 2001). All P2Y receptors of the rat but $\mathrm{P} 2 \mathrm{Y}_{12}$ mediate increases in inositol phosphates (IPs) (Ralevic and Burnstock, 1998), and P2 $\mathrm{Y}_{12}$ mediates an inhibition of adenylyl cyclase (Hollopeter et al., 2001).

ATP is released from various cells including fibroblast-like,

Received Feb. 27, 2003; revised June 13, 2003; accepted June 16, 2003.

This work was supported by European Commission Grant QLRT-2000-00929 and by grants from the Austrian Science Fund (Fonds zur Foerderung der Wissenschaftlichen Forschung; P14951 and P15797) and from the Virologie Fonds of the Medical Faculty of the University of Vienna. We are indebted to Dr. M. Freissmuth for carefully reading this manuscript.

Correspondence should be addressed to Stefan Boehm, Institute of Pharmacology, University of Vienna, Waehringerstrasse 13a, A-1090 Vienna, Austria. E-mail: stefan.boehm@univie.ac.at.

Copyright $\odot 2003$ Society for Neuroscience $\quad$ 0270-6474/03/237479-10\$15.00/0 epithelial, endothelial, glial, and neuronal cells (von Kugelgen et al., 1994; Schlosser et al., 1996; Wang et al., 1996; Lazarowski et al., 2000; Ostrom et al., 2000). ATP release from non-neural cells is $\mathrm{Ca}^{2+}$ independent and can be elicited by different stimuli such as hypotonic solutions (Wang et al., 1996), mechanical stimulation (Schlosser et al., 1996), or exchange of culture media (Lazarowski et al., 2000; Ostrom et al., 2000). In neurons, ATP is stored in vesicles and thus released by exocytosis (Zimmermann, 1994). Vesicle exocytosis occurs spontaneously at a slow rate and is accelerated when transmembrane $\mathrm{Ca}^{2+}$ entry is triggered by depolarization-induced opening of voltage-gated $\mathrm{Ca}^{2+}$ channels (Matthews, 1996). Therefore, neuronal ATP release is depolarization and $\mathrm{Ca}^{2+}$ dependent (von Kugelgen et al., 1994).

In non-neural tissues, such as liver, kidney, bones, and blood vessels, released nucleotides subserve autocrine-paracrine functions by activating certain P2Y receptors (Gerasimovskaya et al., 2002; Junankar et al., 2002; Schwiebert et al., 2002; Torres et al., 2002; You et al., 2002). In neurons, action potential- and $\mathrm{Ca}^{2+}$ dependent release of ATP contributes to synaptic transmission via $\mathrm{P} 2 \mathrm{X}$ receptors (Robertson et al., 2001); however, much less is known about the activation of neuronal P2Y receptors by released nucleotides. One known example is the ATP-mediated autocrine inhibition of voltage-gated $\mathrm{Ca}^{2+}$ channels in bovine chromaffin cells, but the $\mathrm{P} 2 \mathrm{Y}$ receptor that was involved remained unknown (Currie and Fox, 1996). To investigate how different P2Y receptors are activated by nucleotides released from neuronal sources, we used PC12 cells. These rat phaeochromo- 
cytoma cells are ontogenetically related to sympathetic neurons and release transmitters in an exocytotic manner (Greene and Tischler, 1976; Fisher and Burgoyne, 1999). Aside from $\mathrm{P} 2 \mathrm{X}_{1}$ through $\mathrm{P}_{2} \mathrm{X}_{6}, \mathrm{PC} 12$ cells express RNA for $\mathrm{P}_{2} \mathrm{Y}_{2}, \mathrm{P}_{2} \mathrm{Y}_{4}, \mathrm{P} 2 \mathrm{Y}_{6}$, and $\mathrm{P}_{2} \mathrm{Y}_{12}$ receptors (Arslan et al., 2000). Taking the synthesis of IPs and the reduction of cAMP accumulation as measures of receptor activation, we show that neuronal $\mathrm{P} 2 \mathrm{Y}$ receptors are activated in an autocrine-paracrine manner as described previously for non-neural cells. However, diphosphate- and triphosphate-sensitive receptors are differentially activated by spontaneous and depolarizationevoked nucleotide release.

\section{Materials and Methods}

Materials. $\left[2,8-{ }^{3} \mathrm{H}\right]$ adenine (specific activity $32 \mathrm{Ci} / \mathrm{mmol}$ ) and myo$\left[{ }^{3} \mathrm{H}\right]$ inositol $(74.7 \mathrm{Ci} / \mathrm{mmol})$ were obtained from NEN (Vienna, Austria). Na-UTP, Na-UDP, $\mathrm{Na}_{2}$-ATP, Na-ADP, 4-(3-butoxy-4-methoxybenzyl) imidazoline-2-one (RO 20-1724), 3' , $^{\prime}$-cAMP, suramin, apyrase (grade VII, with an $\sim 1: 1$ ratio in ATPase and ADPase activity), 2-methylthio-AMP, 2-methylthio-ATP, pyridoxal-phosphate-6-azophenyl-2', $4^{\prime}$-disulfonic acid tetrasodium (PPADS), and 2-p-(2-carboxyethyl)phenethylamino- $5^{\prime}-\mathrm{N}$ ethylcarboxamido-adenosine (CGS 21680) were purchased from Sigma (Vienna, Austria). 2-Chloro- $N^{6}$-methyldeoxyadenosine 3',5' -biphosphate (MRS 2216) was a gift of Dr. K. A. Jacobson (National Institute of Diabetes and Digestive and Kidney Diseases, Bethesda, MD).

Cell culture and transfection methods. PC12 cells were obtained from the European Collection of Animal Cell Cultures (Salisbury, UK), plated onto collagen-coated (Biomedical Technologies, Stoughton, MA) sixwell culture dishes (NUNC, Roskilde, Denmark), and kept in OptiMEM (Invitrogen, Vienna, Austria) supplemented with $0.2 \mathrm{~mm}$ L-glutamine (HyClone, Aalst, Belgium), 25,000 IU/1 ${ }^{-1}$ penicillin and $25 \mathrm{mg} / \mathrm{l}^{-1}$ streptomycin (Sigma, Vienna, Austria), 5\% fetal calf serum, and 10\% horse serum (both from Invitrogen). Once per week, cell cultures were split, and the medium was exchanged twice per week.

For the generation of $\mathrm{PC} 12$ cell clones stably expressing either the rat $\mathrm{P}_{2} \mathrm{Y}_{1}$ receptor linked to the green fluorescent protein $\left(\mathrm{P}_{2} \mathrm{Y}_{1}-\mathrm{GFP}\right)$ or the rat $\mathrm{P} 2 \mathrm{Y}_{2}$ receptor, $15 \mu \mathrm{g}$ of a rat $\mathrm{P}_{2} \mathrm{Y}_{1}$-enhanced GFP expression vector (kindly provided by Dr. G. Reiser, Magdeburg, Germany) (Vohringer et al., 2000) or $15 \mu \mathrm{g}$ of the expression vector pcDNA3 containing the coding sequence for the rat $\mathrm{P}_{2} \mathrm{Y}_{2}$ receptor (kindly provided by Dr. T. Webb, Leicester, UK) was mixed with $50 \mu$ l of the TransFast transfection reagent (Promega, Mannheim, Germany) and added to semiconfluent PC12 cell cultures in serum-free medium. After a $1 \mathrm{hr}$ incubation at $37^{\circ} \mathrm{C}$, 2 vol of serum-free medium and the appropriate amount of serum (as above) were added. Forty-eight hours after transfection, this medium was exchanged for a medium supplemented with $500 \mu \mathrm{g} / \mathrm{ml}$ neomycin (G418) to allow for selection of drug resistance. This selection medium was replaced every 3-4 d until distinct islands of surviving cells were visible. Individual clones of antibiotic-resistant cells were transferred to 24 -well plates and grown in medium containing $200 \mu \mathrm{g} / \mathrm{ml}$ neomycin.

Northern blot analysis. Northern blots were performed as described previously for P2Y receptors expressed in primary cultures of sympathetic neurons (Vartian et al., 2001). After extraction from PC12 cell cultures, $30 \mu \mathrm{g}$ of RNA per lane was separated by electrophoresis through formaldehyde containing $1.5 \%$ agarose gels and transferred to nylon membranes. Subsequent to UV cross-linkage, membranes were hybridized overnight at $65^{\circ} \mathrm{C}$ in a hybridization solution containing $50 \mathrm{~mm}$ PIPES, pH 6.5, $100 \mathrm{~mm} \mathrm{NaCl}, 50 \mathrm{~mm}$ sodium phosphate buffer, $\mathrm{pH}$ 7.0, 1 mM EDTA, pH 8.0, and 5\% SDS. After hybridization, the blots were washed twice in $5 \% \mathrm{SDS}, 1 \times \mathrm{SSC}$ at $65^{\circ} \mathrm{C}$ for $15 \mathrm{~min}$, and finally exposed to $\mathrm{x}$-ray films. Thereafter, probes were removed from the membranes, and blots were subjected to further hybridization with additional P2Y receptor-specific probes.

Cloned fragments of $\mathrm{P} 2 \mathrm{Y}_{1}, \mathrm{P}_{2} \mathrm{Y}_{2}, \mathrm{P}_{2} \mathrm{Y}_{4}$, and $\mathrm{P} 2 \mathrm{Y}_{6}$ were used as probes for hybridization. The corresponding PCR fragments were amplified from cDNA obtained by reverse transcription of total RNA isolated from rat sympathetic neurons as described (Vartian et al., 2001). The PCR fragments were separated by electrophoresis through a $2 \%$ agarose gel, isolated, and cloned into pCR3.1 vector (Invitrogen). Plasmid DNA was isolated from positive clones and sequenced to verify the P2Y receptor identity. EcoRI fragments carrying the $\mathrm{P} 2 \mathrm{Y}$ receptor sequences were labeled with $\left[\alpha-{ }^{32} \mathrm{P}\right]$ deoxycytidine triphosphate by random priming using the Prime-a-Gene labeling system (Promega).

Determination of inositol phosphates. The method for determining IPs was adapted from that used previously for primary neuronal cell cultures (Bofill-Cardona et al., 2000) as follows. Cells were grown to confluence and incubated in serum-free and inositol-free DMEM supplemented with myo- $\left[{ }^{3} \mathrm{H}\right]$ inositol $(2.5 \mu \mathrm{Ci} / \mathrm{ml})$ for $48 \mathrm{hr}$. Thereafter, the medium was exchanged for OptiMEM supplemented with $10 \mathrm{~mm} \mathrm{LiCl} \mathrm{for} 20 \mathrm{~min}$ to block inositol monophosphatase (Phiel and Klein, 2001). Antagonists or apyrase $(1 \mathrm{U} / \mathrm{ml})$ were added together with $\mathrm{LiCl}$ when appropriate. Subsequently, the cells were incubated for an additional $30 \mathrm{~min}$ (unless indicated otherwise) in a buffer ( $120 \mathrm{~mm} \mathrm{NaCl}, 3 \mathrm{~mm} \mathrm{KCl}, 2 \mathrm{mM} \mathrm{MgCl}$, $2 \mathrm{~mm} \mathrm{CaCl}_{2}, 20 \mathrm{~mm}$ glucose, $10 \mathrm{~mm}$ HEPES, $10 \mathrm{~mm} \mathrm{LiCl}$, adjusted to $\mathrm{pH}$ 7.4 with $\mathrm{NaOH}$ ) containing one or more of the following: agonists, antagonists, apyrase, $\mathrm{CdCl}_{2}(1 \mathrm{~mm})$, and/or $100 \mathrm{~mm} \mathrm{KCl} \mathrm{(} \mathrm{NaCl}$ was reduced accordingly). Finally, cells were lysed in boiling EDTA (10 mM) solution. After centrifugation of samples, an aliquot of the supernatant was removed to estimate the total water-soluble radioactivity. The remainder was applied to anion exchange chromatography columns (Dowex AG 1-X8; Bio-Rad, Vienna, Austria) and washed three times with $3 \mathrm{ml}$ of $\mathrm{H}_{2} \mathrm{O}$. Columns were then washed with $10 \mathrm{ml}$ of $50 \mathrm{~mm}$ ammonium formate, and finally inositol monophosphate $\left(\mathrm{IP}_{1}\right)$ was eluted with $6 \mathrm{ml}$ of $0.18 \mathrm{M}$ ammonium formate and $0.1 \mathrm{M}$ formic acid and quantitated by liquid scintillation counting (Bofill-Cardona et al., 2000). In some experiments, the radioactivity remaining in the pellet was also determined.

The radioactivity in the fraction of $\mathrm{IP}_{1}$ was expressed as percentage of the water-soluble radioactivity in the cells, which consists mainly of inositol (Bofill-Cardona et al., 2000). In initial experiments, the radioactivity in the $\mathrm{IP}_{1}$ fraction was also calculated as percentage of the radioactivity in the pellet; however, these values displayed large variations between experiments (see Fig. 1A) and thus were not used routinely. Nucleotides or bradykinin $(1 \mu \mathrm{M})$ reproducibly caused time-dependent increases in $\mathrm{IP}_{1}$ when compared with the values obtained in their absence (see Fig. $1 \mathrm{~A}$ ). Nevertheless, the extent of basal and agonist-induced $\mathrm{IP}_{1}$ accumulation may vary between different preparations. Therefore, the $\mathrm{IP}_{1}$ values obtained after a $30 \mathrm{~min}$ incubation in the presence of nucleotides, bradykinin, apyrase, $\mathrm{CdCl}_{2}$, and $\mathrm{KCl}$, respectively, were normalized to the values obtained after a $30 \mathrm{~min}$ incubation in their absence within the same preparation (normalized to basal).

Determination of cAMP. The accumulation of cAMP in PC12 cell cultures was determined as described previously (Unterberger et al., 2002). After labeling of cellular purines with tritiated adenine $(2.5 \mu \mathrm{Ci} / \mathrm{ml}$ for 12 $\mathrm{hr}$ ), the medium was replaced by the buffer described above supplemented with $100 \mu \mathrm{M}$ of the phosphodiesterase inhibitor RO 20-1724 and $1 \mathrm{U} / \mathrm{ml}$ adenosine deaminase. Dishes were then kept at room temperature for $105 \mathrm{~min}$. During the last $15 \mathrm{~min}$ of this incubation period, the adenosine $\mathrm{A}_{2 \mathrm{~A}}$ receptor agonist CGS 21680 , ADP $(10 \mu \mathrm{M})$, apyrase (1 $\mathrm{U} / \mathrm{ml}), \mathrm{CdCl}_{2}(1 \mathrm{~mm})$ and $100 \mathrm{~mm} \mathrm{KCl}(\mathrm{NaCl}$ was reduced accordingly) were also included in the medium. Where indicated, the $\mathrm{P}_{2} \mathrm{Y}_{12}$ receptor antagonist 2MesAMP (Hollopeter et al., 2001) was present for the last 25 $\mathrm{min}$. The incubation was terminated by exchanging the buffer for $1 \mathrm{ml}$ of $2.5 \%$ perchloric acid containing $100 \mu \mathrm{M}$ nonlabeled cAMP followed by a $20 \mathrm{~min}$ incubation at $4^{\circ} \mathrm{C}$. Subsequently, cAMP was separated from the other purines by a chromatographic procedure described previously (Unterberger et al., 2002). Finally, radioactivity within the samples obtained was determined by liquid scintillation counting.

The radioactivity in the fraction of cAMP was expressed as percentage of the total radioactivity extracted from the cells. Stimulation of PC12 cells with the adenosine $\mathrm{A}_{2 \mathrm{~A}}$ receptor agonist CGS 21680 caused a reproducible increase in these values of cAMP, but the extent of basal and stimulated cAMP synthesis may vary between different preparations (Unterberger et al., 2002). Therefore, the values of cAMP obtained in the presence of CGS 21680 were normalized to the values obtained in its absence within the same preparation (normalized to basal).

Electrophysiology. Currents through M-type $\mathrm{K}^{+}\left(K_{\mathrm{M}}\right)$ channels were determined as described previously for primary neuronal cell cultures (Scholze et al., 2002). Experiments were performed at room temperature 
$\left(20-24^{\circ} \mathrm{C}\right)$ on isolated PC12 cells using the perforated-patch modification of the patch-clamp technique, which prevents rundown of $\mathrm{M}$ currents $\left(I_{\mathrm{M}}\right)$. Patch pipettes were pulled (Flaming-Brown puller, Sutter Instruments, Novato, CA) from borosilicate glass capillaries (Science Products, Frankfurt/Main, Germany) and front-filled with a solution consisting of (in mM): $75 \mathrm{~K}_{2} \mathrm{SO}_{4}, 55 \mathrm{KCl}, 8 \mathrm{MgCl}_{2}$, and $10 \mathrm{HEPES}$, adjusted to $\mathrm{pH} 7.3$ with $\mathrm{KOH}$. Then, electrodes were back-filled with the same solution containing $200 \mu \mathrm{g} / \mathrm{ml}$ amphotericin B (in $0.8 \%$ DMSO), which yielded tip resistencies of $1-3 \mathrm{M} \Omega$. PC12 cells were submerged in and continuously superfused with (in mM): $140 \mathrm{NaCl}, 6.0 \mathrm{KCl}, 2.0 \mathrm{CaCl}_{2}$, $2.0 \mathrm{MgCl}_{2}, 20$ glucose, 10 HEPES, adjusted to $\mathrm{pH} 7.4$ with $\mathrm{NaOH}$. Tetrodotoxin $(0.5 \mu \mathrm{M})$ was included to suppress voltage-activated $\mathrm{Na}^{+}$currents. Superfusion was performed by the use of a DAD-12 drug application device (Adams \& List, Westbury, NY). $I_{\mathrm{M}}$ relaxations were evoked once every $20 \mathrm{sec}$ by $1 \mathrm{sec}$ hyperpolarizing voltage steps from -30 to -55 $\mathrm{mV}$; the difference between current amplitudes $20 \mathrm{msec}$ after the onset of hyperpolarizations and $20 \mathrm{msec}$ before re-depolarization was taken as a measure for $I_{\mathrm{M}}$. Amplitudes obtained during the application of ADP $(b)$ were compared with those measured before $(a)$ and after $(c)$ application of the nucleotide by calculating $100-(200 b /[a+c])=\%$ inhibition (Scholze et al., 2002).

Statistics. All data represent arithmetic means \pm SEM; $n$ represents number of culture dishes or of single cells in electrophysiological experiments. If error bars are not shown in Figures, they were smaller than the symbols. Concentration-response curves were fitted to experimentally obtained data by the ALLFIT program (De Lean et al., 1978). Significances of differences between single data points were evaluated by the nonparametric Mann-Whitney test, and $p$ values $<0.05$ were accepted as indicators of statistically significant differences.

\section{Results}

Activation of endogenous $\mathrm{P} 2 \mathrm{Y}_{2}$ receptors by added nucleotides

In nondifferentiated PC12 cells, ATP and UTP have been found either to stimulate an accumulation of IPs (Murrin and Boarder, 1992) or to leave $\mathrm{IP}_{3}$ unchanged (Arslan et al., 2000). To verify whether the present PC12 cell clone was capable of synthesizing IPs in response to nucleotides, PC12 cells were labeled with tritiated myo-inositol and preincubated in $10 \mathrm{~mm} \mathrm{LiCl}$ for $20 \mathrm{~min}$ to block inositol phosphatases. Thereafter, the cells were incubated for various periods of time in $10 \mu \mathrm{M} U \mathrm{TP}$, in $1 \mu \mathrm{M}$ bradykinin for comparison, or in buffer lacking agonists. As shown in Figure $1 \mathrm{~A}$, both UTP and bradykinin caused time-dependent increases in the radioactivity retrieved in the fraction of $\mathrm{IP}_{1}$, which hardly changed in the absence of agonists.

When UTP was applied for $30 \mathrm{~min}$ at different concentrations, its effect was concentration-dependent, with half-maximal stimulation between 1 and $10 \mu \mathrm{M}$. At concentrations up to $100 \mu \mathrm{M}$, ATP was equi-effective to UTP in stimulating $\mathrm{IP}_{1}$ synthesis, but at higher concentrations, ATP was much more effective than UTP. In contrast, ADP, UDP, and 2MeSATP at up to $100 \mu \mathrm{M}$ did not cause significant changes in $\mathrm{IP}_{1}$ accumulation (Fig. $1 B$ ).

To further elucidate which $\mathrm{P} 2$ receptors mediated these effects, two P2 receptor antagonists, suramin and PPADS, were used. Suramin, at 10-100 $\mu \mathrm{M}$, reduced the $\mathrm{IP}_{1}$ stimulating effect of $10 \mu \mathrm{M}$ UTP in a concentration-dependent manner, whereas PPADS (100 $\mu \mathrm{M})$ had no such effect. PPADS also failed to attenuate the effect of $10 \mu \mathrm{M}$ ATP (Fig. 2A) but reduced the effect of $1 \mathrm{~mm}$ ATP; in its presence, ATP was equipotent and equi-effective to UTP applied alone in stimulating $\mathrm{IP}_{1}$ synthesis: half-maximal effects occurred at $3.2 \pm 1.2 \mu \mathrm{M}$ UTP and at $4.7 \pm 1.7 \mu \mathrm{M}$ ATP (plus $100 \mu \mathrm{M}$ PPADS), and the maximum with both nucleotides was a 2.5 -fold stimulation over basal (Fig. 2 B). PPADS (100 $\mu \mathrm{M})$ entirely blocks P2X receptormediated events in PC12 cells (Vartian and Boehm, 2001). Therefore, these results suggest that ATP concentrations above $100 \mu \mathrm{M}$ enhance $\mathrm{IP}_{1}$ accumulation via activation of both $\mathrm{P} 2 \mathrm{Y}$ and $\mathrm{P} 2 \mathrm{X}$ re-
A
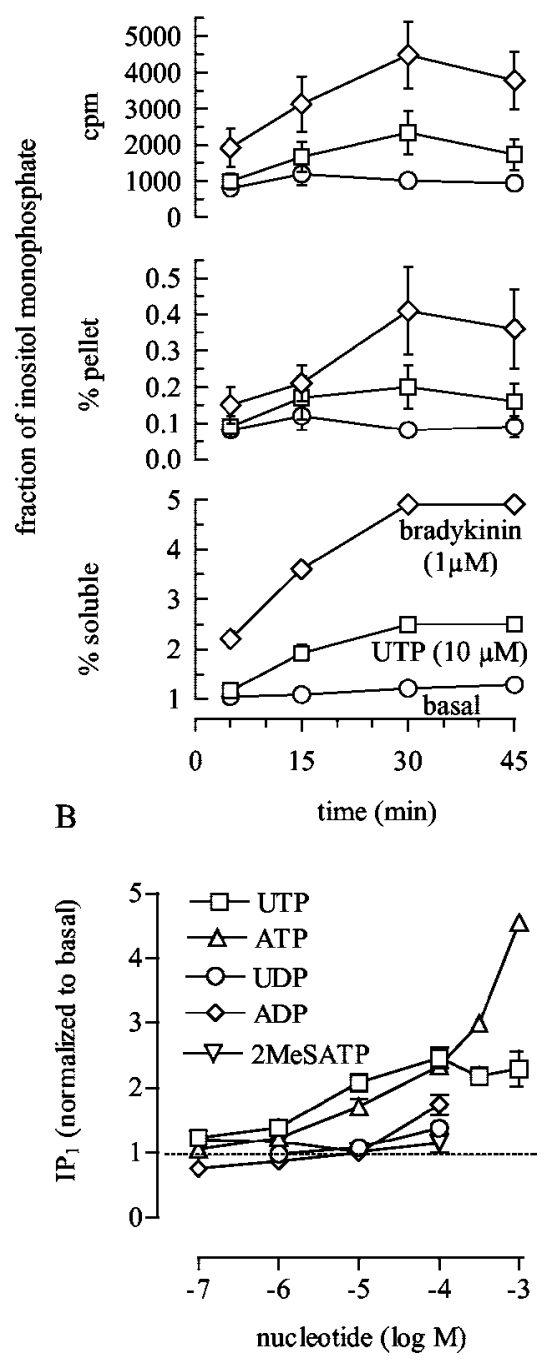

Figure 1. Enhancement of IP accumulation by nucleotides and bradykinin. A, After loading with myo- $\left[{ }^{3} \mathrm{H}\right]$ inositol, $\mathrm{PC} 12$ cells were preincubated in LiCl $(10 \mathrm{~mm})$ for $20 \mathrm{~min}$. During subsequent incubation periods ( $5-45 \mathrm{~min}$ ), LiCl alone (basal; $\bigcirc$ ), LiCl plus UTP (10 $\mu \mathrm{m} ; \square)$, or LiCl plus bradykinin $(1 \mu \mathrm{m} ; \diamond)$ were present. The amount of radioactivity retrieved within the fraction of inositol monophosphate $\left(\mathbb{P}_{1}\right)$ after these incubation periods is shown as counts per minute (cpm; top panel), as percentage of the total radioactivity in the pellet (\% pellet; middle panel), or as percentage of the total water-soluble radioactivity extracted from the cell cultures (\% soluble; bottom panel). The results stem from two independent experiments, each performed in triplicate (i.e., $n=6$ ). $B$, After loading with myo- $\left[{ }^{3} \mathrm{H}\right]$ inositol and preincubation in $\mathrm{LiCl}(10 \mathrm{~mm})$, the cells were incubated for $30 \mathrm{~min}$ in LiCl alone or in LiCl plus the indicated concentrations of nucleotides. The amount of radioactivity retrieved within the fraction of inositol monophosphate $\left(\mathbb{P}_{1}\right)$ was calculated as percentage of the total water-soluble radioactivity extracted from the cell cultures, and values obtained in the presence of nucleotides were normalized to the data obtained in their absence (normalized to basal). In the absence of nucleotides, $3822.9 \pm 222.0 \mathrm{cpm}$ were retrieved in the $\mathbb{P}_{1}$ fraction $(n=36)$.

ceptors. UTP, in contrast, does not activate P2X receptors (Ralevic and Burnstock, 1998) and thus stimulated $\mathrm{IP}_{1}$ synthesis only via P2Y receptors. Among the $\mathrm{P} 2 \mathrm{Y}$ receptors expressed in the rat, $\mathrm{P}_{2} \mathrm{Y}_{2}$ and $\mathrm{P}_{2} \mathrm{Y}_{4}$ receptors are activated by both ATP and UTP (Kennedy et al., 2000). Previously, rat $\mathrm{P}_{2} \mathrm{Y}_{4}$ receptors were found to be blocked by PPADS (Suarez-Huerta et al., 2001) but not by suramin (Bogdanov et al., 1998), exactly the opposite of the present findings. Therefore, the present results are compatible with $\mathrm{P}_{2} \mathrm{Y}_{2}$ receptors mediating the nucleotide-dependent IP synthesis.

To investigate in further detail which P2Y receptor subtypes 
might be involved in the nucleotidedependent synthesis of $\mathrm{IP}_{1}$ as described above, we performed Northern blots to check for their expression level. Total RNA was isolated from either untreated or NGF-differentiated PC12 cells and compared with RNA from primary cultures of rat superior cervical ganglia (Vartian et al., 2001). After separation by agarose gel electrophoresis and blotting, the extracted RNA was analyzed with probes specific for $\mathrm{P}_{2} \mathrm{Y}_{1}, \mathrm{P}_{2} \mathrm{Y}_{2}, \mathrm{P}_{2} \mathrm{Y}_{4}$, and $\mathrm{P} 2 \mathrm{Y}_{6}$. As shown in Figure $2 C$, considerable amounts of RNA coding for $\mathrm{P}_{2} \mathrm{Y}_{2}$, but none for $\mathrm{P} 2 \mathrm{Y}_{1}, \mathrm{P}_{2} \mathrm{Y}_{4}$ (data not shown), or $\mathrm{P}_{2} \mathrm{Y}_{6}$, were detected in nondifferentiated PC12 cells. RNA isolated from primary cultures of rat superior cervical ganglia gave positive signals for $\mathrm{P}_{2} \mathrm{Y}_{1}, \mathrm{P}_{2} \mathrm{Y}_{2}$, and $\mathrm{P} 2 \mathrm{Y}_{6}$ (Fig. 2C), but not for $\mathrm{P}_{2} \mathrm{Y}_{4}$ (data not shown). Previously, transcripts for $\mathrm{P}_{2} \mathrm{Y}_{4}$ and $\mathrm{P} 2 \mathrm{Y}_{6}$ receptors, but none for $\mathrm{P}_{2} \mathrm{Y}_{1}$ receptors, had been detected in PC12 cells by RT-PCR (Arslan et al., 2000; Unterberger et al., 2002). Thus, nondifferentiated PC12 cells express high levels of $\mathrm{P}_{2} \mathrm{Y}_{2}$, but of no other phospholipase C-linked $\mathrm{P} 2 \mathrm{Y}$ receptor.

After differentiation of PC12 cells with recombinant human $\beta$-nerve growth factor $(50 \mathrm{ng} / \mathrm{ml}$ for $5 \mathrm{~d}), \mathrm{P}_{2} \mathrm{Y}_{2}$ receptorspecific RNA was slightly decreased, and the expression of $\mathrm{P}_{2} \mathrm{Y}_{6}$ receptors was induced (Fig. 2C). In parallel, the UTPdependent $\mathrm{IP}_{1}$ accumulation was reduced in nerve growth factor-treated cells as compared with nontreated PC12 cells, and the $\mathrm{P}^{2} \mathrm{Y}_{6}$ receptor agonist UDP still failed to significantly alter $\mathrm{IP}_{1}$ (Fig. $2 \mathrm{D}$ ). This corroborates that the $\mathrm{P} 2 \mathrm{Y}_{2}$ but no other $\mathrm{P} 2 \mathrm{Y}$ receptor subtype mediates the nucleotide-dependent $\mathrm{IP}_{1}$ accumulation in $\mathrm{PC} 12$ cells.

\section{Autocrine-paracrine activation of endogenous $\mathrm{P}_{2} \mathrm{Y}_{2}$ receptors}

In non-neural cells, such as Madin-Darby canine kidney cells, endogenous $\mathrm{P} 2 \mathrm{Y}$ receptors were found to be activated by endogenous nucleotides released, for instance, in response to the exchange of culture media (Ostrom et al., 2000). To reveal whether endogenous P2Y receptors of PC12 cells may become activated under the present experimental conditions even in the absence of added nucleotides, cultures were incubated in $\mathrm{LiCl}(10 \mathrm{~mm})$ in the presence of apyrase $(1 \mathrm{U} / \mathrm{ml})$; however, the degradation of nucleotides by apyrase did not alter the values of basal IP ${ }_{1}$ accumulation, although the enzyme did abolish the $\mathrm{IP}_{1}$-stimulating effect of $10 \mu \mathrm{M}$ ATP (Fig. 3 ). To certify that this inhibitory action of apyrase was not caused by some unspecific effect on IP accumulation or phospholipase Cactivity, the enzyme was also used together with bradykinin; however, apyrase left the IP synthesis in the presence of this peptide unchanged (Fig. 3). Depolarization of PC12 cells by $100 \mathrm{~mm} \mathrm{~K}^{+}$enhanced the $\mathrm{IP}_{1}$ accumulation twofold, i.e., to almost the same extent as the exogenous application of $10 \mu \mathrm{M}$ ATP. This effect of depolarizing $\mathrm{K}^{+}$concentrations was abolished in
$\mathrm{C}$

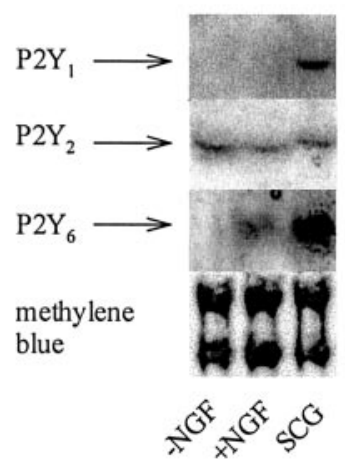

D

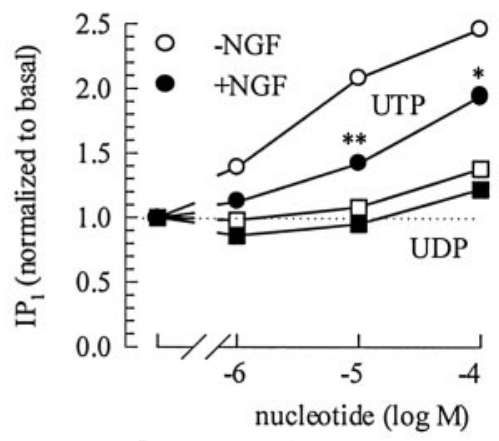

Figure 2. Characterization of the receptor mediating the nucleotide-dependent synthesis of IPs. After loading with myo$\left[{ }^{3} \mathrm{H}\right.$ ]inositol and preincubation in $\mathrm{LiCl}(10 \mathrm{~mm})$, the cells were incubated for $30 \mathrm{~min}$ in $\mathrm{LiCl}$ alone or in $\mathrm{LiCl}$ plus nucleotides. The amount of radioactivity retrieved within the fraction of inositol monophosphate $\left(\mathbb{P}_{1}\right)$ was calculated as percentage of the total water-soluble radioactivity extracted from the cell cultures, and values obtained in the presence of nucleotides were normalized (open bars) or ATP (filled bars) in the absence or presence of the indicated concentrations of suramin or PPADS. $n=6-9 .{ }^{*} p<$ 0.05 and ${ }^{* * *} p<0.001$ versus the value obtained in the presence of UTP only; n.s. indicates no significant difference. In the

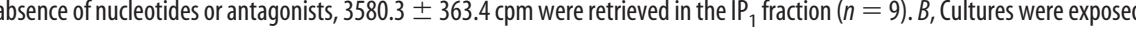
to the indicated concentrations of either UTP alone or ATP plus $100 \mu \mathrm{m}$ PPADS. $n=4-9$. In the absence of nucleotides or (n) $\mathbb{P}_{1}$ fraction $(n=16)$. C, Northern blot analysis performed with total RNA

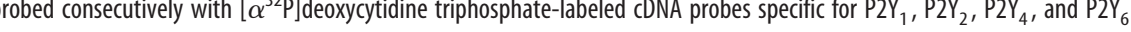
(ue. D, PC12 cells had been treated with nerve growth factor (+NGF) $(50 \mathrm{ng} / \mathrm{ml}$ for $5 \mathrm{~d})$ or remained untreated (-NGF). The

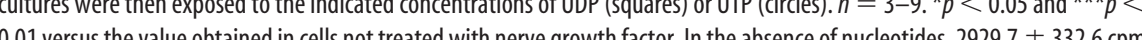
were retrieved in the $\mathbb{P}_{1}$ fraction of NGF-treated cells $(n=7)$, and $3784.3 \pm 264.8 \mathrm{cpm}$ were retrieved in the $\mathbb{I P}_{1}$ fraction of untreated cells ( $n=7 ; p=0.12$ vs NGF-treated cells).

the presence of apyrase, which indicates that it was caused by the release of endogenous nucleotides. In addition, the effect was also attenuated in the presence of $1 \mathrm{mM} \mathrm{Cd}^{2+}$ (Fig. 3), which prevents $\mathrm{Ca}^{2+}$ entry via voltage-gated $\mathrm{Ca}^{2+}$ channels and thereby suppresses depolarization-evoked transmitter release (Boehm, 1999). Thus, the stimulation of $\mathrm{IP}_{1}$ synthesis by endogenously released nucleotides required depolarization-evoked release.

\section{Autocrine-paracrine activation of endogenous \\ $\mathrm{P}_{2} \mathrm{Y}_{12}$ receptors}

Apart from $\mathrm{P}_{2} \mathrm{Y}_{2}$ receptors, as shown above, $\mathrm{PC} 12$ cells express another endogenous $\mathrm{P} 2 \mathrm{Y}$ receptor: this is a $\mathrm{P} 2 \mathrm{Y}_{12}$ receptor, activation of which causes an inhibition of adenylyl cyclase (Unterberger et al., 2002). In contrast to $\mathrm{P}_{2} \mathrm{Y}_{2}$ receptors, $\mathrm{P} 2 \mathrm{Y}_{12}$ receptors 


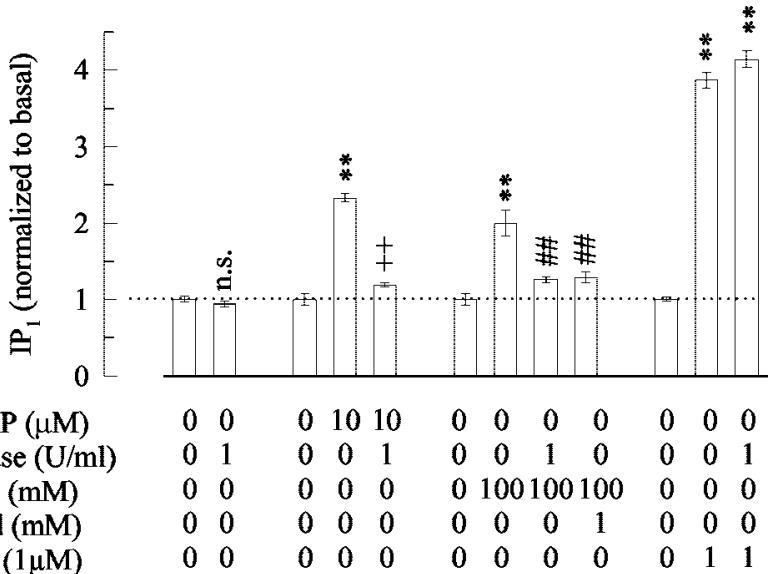

Figure 3. Stimulation of IP synthesis by released nucleotides. After loading with myo$\left[{ }^{3} \mathrm{H}\right]$ inositol and preincubation in $\mathrm{LiCl}(10 \mathrm{mM})$, the cells were incubated for $30 \mathrm{~min}$ in $\mathrm{LiCl}$ alone or LiCl plus the indicated concentrations of apyrase, ATP, bradykinin (Bk), KCl ( $\mathrm{NaCl}$ was reduced accordingly), or $\mathrm{CdCl}_{2}$. The amount of radioactivity retrieved within the fraction of inositol monophosphate $\left(\mathbb{P}_{1}\right)$ was calculated as percentage of the total water-soluble radioactivity extracted from the cell cultures, and values obtained in the presence of the above agents were normalized to the data obtained in their absence (normalized to basal); $n=5-14 .{ }^{* *} p<0.01$ versus the value obtained in the presence of $\mathrm{LiCl}$ only; ${ }^{++} p<0.01$ versus the value obtained in the presence of LiCl plus ATP; ${ }^{\# \#} p<0.01$ versus the value obtained in the presence of $\mathrm{LiCl}$ plus $100 \mathrm{~mm} \mathrm{~K}^{+}$. In the presence of LiCl only, $2968.6 \pm 200.5 \mathrm{cpm}$ were retrieved in the $\mathrm{IP}_{1}$ fraction $(n=16)$.

are activated by ADP rather than ATP (Hollopeter et al., 2001). To investigate whether this latter receptor might show a different pattern of activation, we measured the formation of cAMP under various conditions. After labeling of PC12 cells with $\left[{ }^{3} \mathrm{H}\right]$ adenine, $339.7 \pm 23.3 \mathrm{cpm}(n=23)$ were retrieved within the fraction of cAMP, which corresponded to $0.060 \pm 0.007 \%$ of the total radioactivity extracted from the cultures. These and all subsequent values were obtained in the presence of the phosphodiesterase inhibitor RO 20-1724 (100 $\mu \mathrm{M})$. Therefore, any druginduced alteration will reflect changes in adenylyl cyclase activity rather than alterations in CAMP degradation (Unterberger et al., 2002). Exposure of PC12 cells to $1 \mu \mathrm{M}$ of the $A_{2 A}$ adenosine receptor agonist CGS 21680 for 15 min increased cellular cAMP by $\sim 20$-fold (Fig. $4 A$ ). In the presence of $10 \mu \mathrm{M}$ ADP, this CGS 21680 -induced accumulation of cAMP was markedly reduced. The P2 $\mathrm{Y}_{12}$ receptor antagonist 2-MeSAMP (10-100 $\mu \mathrm{M}$ ) (Hollopeter et al., 2001) abolished this inhibitory effect of ADP (Fig. $4 C$ ). This corroborates previous results indicating that $\mathrm{P}_{2} \mathrm{Y}_{12}$ receptors mediate an inhibition of adenylyl cyclase in PC12 cells (Kubista et al., 2003).

When 10 or $100 \mu \mathrm{M}$ 2-MeSAMP was applied together with CGS 21680, but in the absence of ADP, the stimulation of cAMP synthesis by the $\mathrm{A}_{2 \mathrm{~A}}$ receptor agonist was enhanced significantly (Fig. $4 B$ ). Furthermore, application of apyrase $(1 \mathrm{U} / \mathrm{ml})$ together with CGS 21680 caused a similar increase in cAMP accumulation as the $\mathrm{P} 2 \mathrm{Y}_{12}$ receptor antagonist (Fig. $4 D$ ). Thus, there was a spontaneous activation of the $\mathrm{P} 2 \mathrm{Y}$ receptor that is negatively linked to adenylyl cyclase. When PC12 cells were depolarized by $100 \mathrm{mM} \mathrm{K}^{+}$, the CGS 21680-induced cAMP accumulation was reduced to approximately the same extent as by $10 \mu \mathrm{M}$ ADP. This inhibition attributable to $\mathrm{K}^{+}$depolarization was attenuated by the addition of apyrase and thus was mediated by released nucleotides. Finally, the inhibitory effect of $100 \mathrm{mM} \mathrm{K}^{+}$was prevented by $1 \mathrm{mM} \mathrm{Cd}^{2+}$ (Fig. $4 D$ ), which indicates a role of $\mathrm{Ca}^{2+}$ dependent vesicle exocytosis. $\mathrm{Cd}^{2+}(1 \mathrm{~mm})$ per se did not alter
A

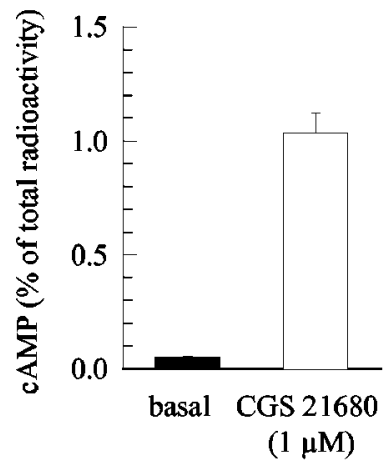

C

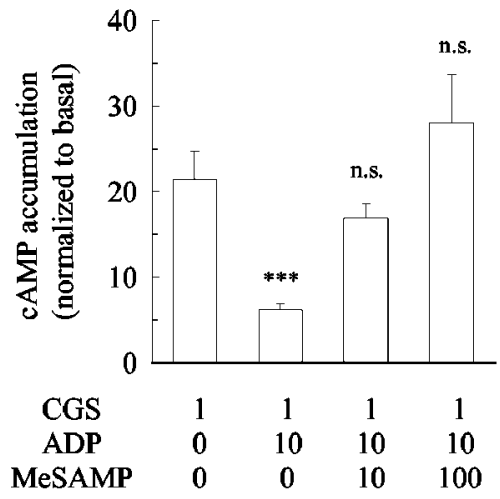

D

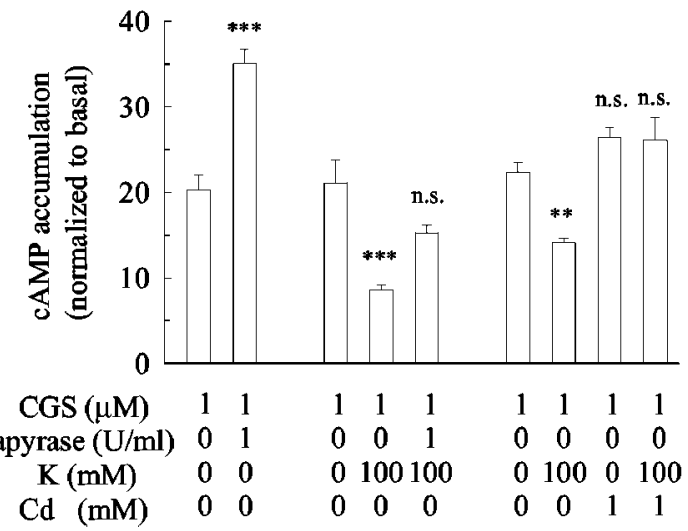

Figure 4. Inhibition of cAMP synthesis by added and released nucleotides. After loading with [ ${ }^{3} \mathrm{H}$ ]adenine, $\mathrm{PC} 12$ cells were incubated in R0 20-1724 (100 $\left.\mu \mathrm{M}\right)$ for $105 \mathrm{~min}$. During the last $15 \mathrm{~min}$ of this incubation period, $1 \mu \mathrm{M}$ CGS 21680 was present either alone or together with the indicated concentrations of additional agents. The amount of radioactivity retrieved within the fraction of CAMP was calculated as percentage of the total radioactivity extracted from the cell cultures, and values obtained in the presence of CGS 21680 were normalized to the data obtained in its absence (normalized to basal). $A$, Cells were incubated in the presence (open bar) or absence (filled bar) of $1 \mu \mathrm{m}$ CGS 21680; $n=41$. B, Cells were incubated in the presence of the indicated concentrations (micromolar) of GS 21680 or 2MeSAMP, or both; $n=6-9$; ${ }^{* *} p<$ 0.01 versus the value obtained in the presence of CGS 21680 only. C, Cells were incubated in the presence of the indicated concentrations (micromolar) of CGS 21680 and ADP or 2MeSAMP, or both; $n=6-9 ; * * * 00.001$ versus the value obtained in the presence of CGS 21680 only; $n . s$. indicates no significant difference. $D$, Cells were incubated in the presence of the indicated concentrations of CGS21680, apyrase, and KCI (NaCl was reduced accordingly) or $\mathrm{CdCl}_{2}$, or both; $n=6-9 ;{ }^{* *} p<0.01$ and ${ }^{* * *} p<0.001$, respectively, versus the value obtained in the presence of CGS 21680 only; n.s. indicates no significant difference. 
the CGS 21680-induced cAMP accumulation. Taken together, these results suggest that $\mathrm{P}_{2} \mathrm{Y}_{12}$ receptors endogenously expressed in PC12 cells are activated to some extent by spontaneously released nucleotides and can be activated further by nucleotides released by $\mathrm{K}^{+}$depolarization.

\section{Autocrine-paracrine activation of overexpressed $\mathrm{P}_{2} \mathrm{Y}_{2}$ receptors}

One of the reasons for the lack of spontaneous $\mathrm{P}_{2} \mathrm{Y}_{2}$ receptor activation as opposed to the spontaneous activation of $\mathrm{P} 2 \mathrm{Y}_{12}$ receptors might be a low number of endogenously expressed $\mathrm{P}_{2} \mathrm{Y}_{2}$ receptors. Therefore, $\mathrm{PC} 12$ cell clones stably overexpressing rat $\mathrm{P} 2 \mathrm{Y}_{2}$ receptors $\left(\mathrm{PC} 12-\mathrm{P} 2 \mathrm{Y}_{2}\right)$ were generated, and three clones (clones 12, 14, and 17) were tested for their capability to synthesize IP $\mathrm{IP}_{1}$ in the absence and presence of UTP. As shown in Figure $5 A$, in clones 12 and 17 , the spontaneous accumulation of $\mathrm{IP}_{1}$ was not different from that in wild-type PC12 cells, whereas in clone 14 it was enhanced by a factor of 3.5. In these three clones, the increases in $\mathrm{IP}_{1}$ synthesis caused by $10 \mu \mathrm{M}$ UTP were $6.3 \pm 0.5$ (clone 12), $6.9 \pm 0.8$ (clone 14), and $8.9 \pm 0.6$ (clone 17)-fold, respectively. In wild-type PC12 cells, in contrast, this UTPinduced increase was only $2.2 \pm 0.15-$ fold (Fig. 5A). Thus, overexpression increased the efficacy of the agonists. In addition, in clone 14 of PC12-P2Y 2 cells, not only the efficacies but also the potencies of both ATP and UTP to stimulate IP 1 synthesis were enhanced as compared with wild-type PC12 cells; half-maximal effects were observed at $1.4 \pm 0.1 \mu \mathrm{M}$ (ATP) and $1.6 \pm 0.4 \mu \mathrm{M}$ (UTP), respectively, and the maximum was a ninefold stimulation over basal (Fig. 5B).

The above results reveal that in $\mathrm{PC} 12-\mathrm{P} 2 \mathrm{Y}_{2}$ cells, the ability of $\mathrm{P}_{2} \mathrm{Y}_{2}$ receptors to mediate nucleotide-dependent $\mathrm{IP}_{1}$ synthesis was markedly enhanced. To evaluate whether overexpressed $\mathrm{P} 2 \mathrm{Y}_{2}$ receptors might become activated by spontaneously released nucleotides, we further used clone 14, which displayed the highest levels of spontaneous as well as UTP-dependent $\mathrm{IP}_{1}$ synthesis (Fig. 5A). Nevertheless, apyrase $(1 \mathrm{U} / \mathrm{ml})$ failed to significantly reduce the accumulation of $\mathrm{IP}_{1}$ in the absence of exogenous nucleotides, although the enzyme did reduce the stimulating effect of ATP. Depolarization of PC12-P2Y $\mathrm{Y}_{2}$ cells by $100 \mathrm{mM} \mathrm{K}^{+}$enhanced the $\mathrm{IP}_{1}$ accumulation to almost the same extent as $10 \mu \mathrm{M}$ ATP (Fig. 5C), as described above for untransfected PC12 cells (Fig. 3). Again, in PC12-P2Y $\mathrm{Y}_{2}$ cells the $\mathrm{IP}_{1^{-}}$ increasing action of $100 \mathrm{mM} \mathrm{K}^{+}$was abolished in the presence of apyrase and by the $\mathrm{Ca}^{2+}$ channel blockade by $\mathrm{Cd}^{2+}$ (Fig. $5 C$ ), as it was in untransfected PC12 cells. Thus, overexpression of $\mathrm{P}_{2} \mathrm{Y}_{2}$ receptors was not sufficient to allow for a stimulation of $\mathrm{IP}_{1}$ synthesis by released nucleotides in the absence of depolarizing stimuli.

\section{Autocrine-paracrine activation of heterologously expressed $\mathrm{P}_{2} \mathrm{Y}_{1}$ receptors}

$\mathrm{P}_{2} \mathrm{Y}_{2}$ receptors are equipotently activated by ATP and UTP, but they are insensitive to nucleoside diphosphates (Nicholas et al., 1996). $\mathrm{P}_{2} \mathrm{Y}_{12}$ receptors, in contrast, are potently activated by ADP (Hollopeter et al., 2001). To learn whether another P2Y receptor that accepts diphosphates as agonists might also be activated by spontaneously released nucleotides, $\mathrm{PC} 12$ cell lines permanently expressing rat $\mathrm{P} 2 \mathrm{Y}_{1}$ receptors linked to eGFP $\left(\mathrm{PC} 12-\mathrm{P} 2 \mathrm{Y}_{1}\right)$ were generated. Previously, this fusion protein was found to mediate a stimulation of IP synthesis about as efficiently as nontagged rat $\mathrm{P}_{2} \mathrm{Y}_{1}$ receptors (Vohringer et al., 2000). In the three $\mathrm{PC} 12-\mathrm{P} 2 \mathrm{Y}_{1}$ clones that were tested for $\mathrm{IP}_{1}$ accumulation (clones 4, 5, and 8), its synthesis in the absence of added nucleotides was increased by
A
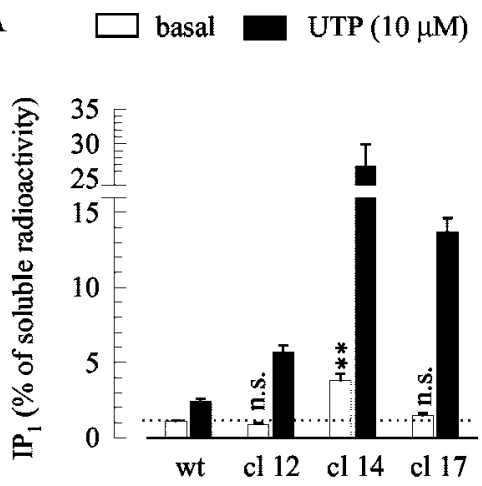

B

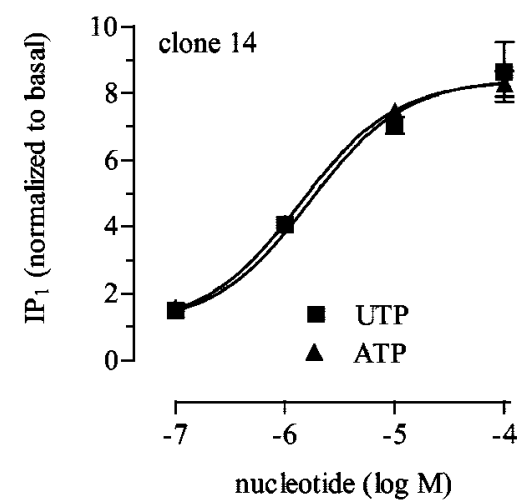

C

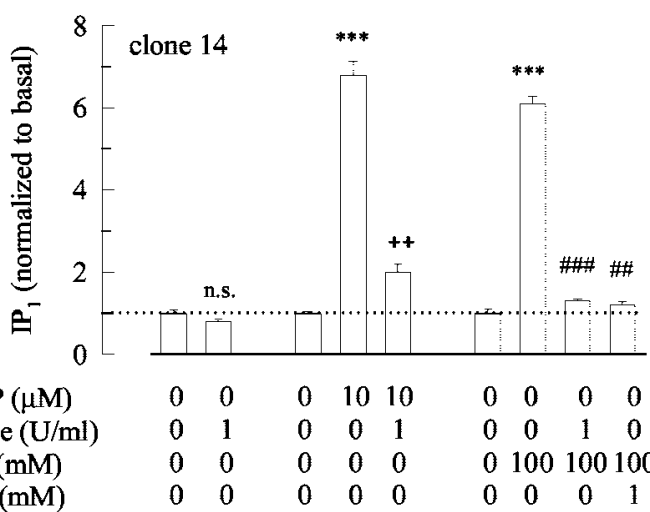

Figure 5. Stimulation of IP synthesis in $\mathrm{P}_{2} \mathrm{Y}_{2}$ receptor-overexpressing cells. After loading with myo- $\left[{ }^{3} \mathrm{H}\right]$ inositol and preincubation in LiCl $(10 \mathrm{mM})$, the cells were incubated for $30 \mathrm{~min}$ in $\mathrm{LiCl}$ alone or LiCl plus the indicated concentrations of apyrase, ATP, UTP, KCl (NaCl was reduced accordingly), or $\mathrm{CdCl}_{2}$. The amount of radioactivity retrieved within the fraction of inositol monophosphate $\left(\mathbb{P}_{1}\right)$ was calculated as percentage of the total water-soluble radioactivity extracted from the cell cultures $(A)$, and values obtained in the presence of the above agents were normalized to the data obtained in their absence (normalized to basal) $(B, C) A$, Either wild-type $\mathrm{PC} 12$ cells or three clones (clones 12,14 , or 17) of $P 2 Y_{2}$ receptor-overexpressing cells were exposed to LiCl (open bars) or to LiCl plus $10 \mu \mathrm{m}$ UTP (filled bars); $n=6$; ${ }^{* *} p<0.01$ for the difference between the value obtained in the presence $\mathrm{LiCl}$ in $\mathrm{P}_{2} \mathrm{Y}_{2}$ receptor-overexpressing cells versus the value in wild-type cells; $n$.s. indicates no significant difference. $B, P C 12-P 2 Y_{2}$ cells of clone 14 were exposed to the indicated concentrations of ATP or UTP; $n=6-9$. C, $P C 12-P 2 Y_{2}$ cells of clone 14 were exposed to the indicated concentrations of one or more of the following: ATP, apyrase, $\mathrm{KCl}$, and $\mathrm{CdCl}_{2} ; n=6-9 ;{ }^{* * *} p<0.001$ versus the value obtained in the presence of $\mathrm{LiCl}$ only; ${ }^{++} p<0.01$ versus the value obtained in the presence of $\mathrm{LiCl}$ plus ATP; $\#<0.01$ and $^{\# \# \#} p<0.001$ versus the value obtained in the presence of LiCl plus $\mathrm{KCl}$. In the absence of nucleotides or other agents, $2210.0 \pm 92.1 \mathrm{cpm}$ were retrieved in the $\mathbb{P}_{1}$ fraction of wild-type $\mathrm{PC} 12$ cells $(n=6), 1595.7 \pm 62.4$ cpm in clone 12 ( $n=6 ; p<0.01$ vs wild type), $5143.6 \pm 390.1$ in clone 14 ( $n=24 ; p<0.001$ vs wild type), and $2744.5 \pm 226.9 \mathrm{cpm}$ in clone 17 ( $n=6 ; p>0.1$ vs wild type). 


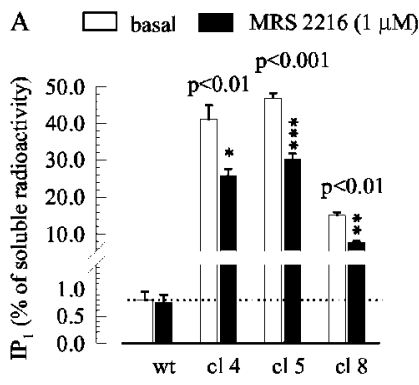

C

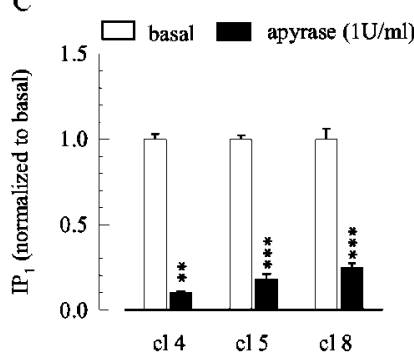

D
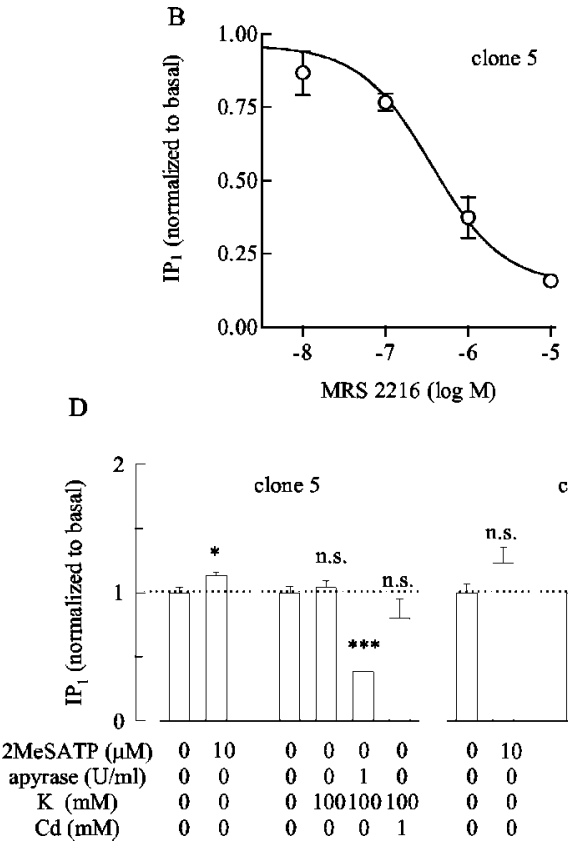

Figure 6. Stimulation of IP synthesis in $\mathrm{P} 2 \mathrm{Y}_{1}$ receptor-expressing cells. After loading with myo- $\left[{ }^{3} \mathrm{H}\right]$ inositol and preincubation in $\mathrm{LiCl}(10 \mathrm{~mm})$, the cells were incubated for $30 \mathrm{~min}$ in $\mathrm{LiCl}$ alone or LiCl plus the indicated concentrations of MRS 2216, apyrase, 2-methylthio ATP (2MeSATP), $\mathrm{KCl}\left(\mathrm{NaCl}\right.$ was reduced accordingly), or $\mathrm{CdCl}_{2}$. The amount of radioactivity retrieved within the fraction of inositol monophosphate $\left(\mathbb{P}_{1}\right)$ was calculated as percentage of the total water-soluble radioactivity extracted from the cell cultures $(A)$, and values obtained in the presence of the above agents were normalized to the data obtained in their absence (normalized to basal) (B[en]D). $A$, Either wild-type $P C 12$ cells or three clones (clones 4, 5, and 8) of $P 2 Y_{1}$ receptor-expressing cells were exposed to $\mathrm{LiCl}$ (open bars) or LiCl plus $1 \mu \mathrm{mMRS} 2216$ (filled bars); $n=6-12$. The $p$ values shown above the bars are related to the differences between the values obtained in the presence of $\mathrm{LiCl}$ in the $\mathrm{P} 2 \mathrm{Y}_{1}$ receptor-expressing cells versus the same value in wild-type PC12 cells; ${ }^{*} p<0.05,{ }^{* *} p<0.01$, and ${ }^{* * *} p<0.001$ versus the value obtained in the absence of MRS 2216, respectively. $B, P C 12-P 2 Y_{1}$ cells of clone 5 were incubated in the indicated concentrations of MRS 2216; $n=4-6$. $C$, Three clones (clones 4, 5, and 8) of $\mathrm{P} 2 \mathrm{Y}_{1}$ receptor-expressing cells were exposed to $\mathrm{LiCl}$ (open bars) or LiCl plus apyrase (filled bars); $n=6-12$; ${ }^{* *} p<0.01$ and ${ }^{* * *} p<0.001$ versus the value obtained in the absence of apyrase, respectively. D, Two clones (clones 5 and 8 ) of $\mathrm{P} 2 \mathrm{Y}_{1}$ receptor-expressing cells were exposed to the indicated concentrations of one or more of the following: 2MeSATP, apyrase, $\mathrm{KCl}$, and $\mathrm{CdCl}_{2} ; n=6-12 ;{ }^{* * *} p<0.001$ versus the value obtained in the presence of LiCl only; n.s. indicates no significant difference. In the absence of nucleotides or other agents, $3178.6 \pm 153.6 \mathrm{cpm}$ were retrieved in the $\mathbb{P}_{1}$ fraction of wild-type $P C 12$ cells $(n=6), 119973.8 \pm 9125.1 \mathrm{cpm}$ in clone 4 ( $n=9 ; p<0.001$ vs wild type), $306452.8 \pm 25304.4$ in clone $5(n=24 ; p<$ 0.001 vs wild type), and $13004.3 \pm 1974.7 \mathrm{cpm}$ in clone 8 ( $n=15 ; p<0.001$ vs wild type).

factors of up to 45 . Addition of $1 \mu \mathrm{M}$ of the $\mathrm{P} 2 \mathrm{Y}_{1}$ receptor antagonist MRS 2216 (Nandanan et al., 1999) significantly reduced these values of spontaneous $\mathrm{IP}_{1}$ accumulation in these three PC12-P2Y $Y_{1}$ clones but had no effect in untransfected PC12 cells (Fig. 6A). This action of MRS 2216 was concentration dependent, with half-maximal effects at $0.37 \pm 0.13 \mu \mathrm{M}$ (Fig. $6 B$ ). This value is in reasonable agreement with the half-maximal concentrations of MRS $2216(0.2 \mu \mathrm{M})$ required to antagonize the stimulation of IP synthesis via $\mathrm{P}_{2} \mathrm{Y}_{1}$ receptors in turkey erythrocytes (Nandanan et al., 1999). Addition of apyrase (1 U/ml) also reduced the spontaneous accumulation of $\mathrm{IP}_{1}$ in the three $\mathrm{PC} 12-\mathrm{P} 2 \mathrm{Y}_{1}$ clones tested by $75 \%$ to $>90 \%$ (Fig. $6 C$ ).

The data shown above indicate that the $\mathrm{P} 2 \mathrm{Y}_{1}$ receptors were highly activated under our routine experimental conditions. This conclusion is supported further by the fact that addition of 2MeSATP $(10 \mu \mathrm{M})$, which potently activates the P2 $\mathrm{Y}_{1}-\mathrm{eGFP}$ fusion protein in human embryonic kidney (HEK) 293 cells (Vohringer et al., 2000), either failed to significantly enhance $\mathrm{IP}_{1}$ accumulation or caused an increase by only $13 \pm 3 \%$ (Fig. $6 D$ ). In untransfected $\mathrm{PC} 12$ cells, for comparison, this $\mathrm{P}_{2} \mathrm{Y}_{1}$ agonist also failed to cause significant changes in $\mathrm{IP}_{1}$ synthesis (Fig. $1 \mathrm{~B}$ ). Depolarization of PC12-P2 $\mathrm{Y}_{1}$ cells by $100 \mathrm{~mm} \mathrm{~K}^{+}$did not enhance the accumulation of $\mathrm{IP}_{1}$, nor did the concomitant application of 1

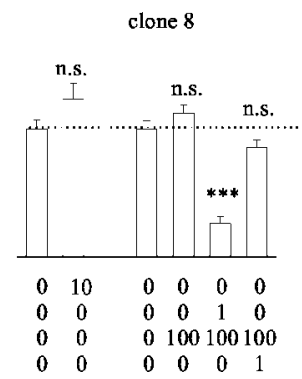

$\mathrm{mM} \mathrm{Cd}^{2+}$ cause any further change. In the presence of $100 \mathrm{mM} \mathrm{K}^{+}$plus $1 \mathrm{U} / \mathrm{ml}$ apyrase, the $\mathrm{IP}_{1}$ values obtained with $\mathrm{PC} 12-\mathrm{P}_{2} \mathrm{Y}_{1}$ cells were significantly lower than those obtained under control conditions and about the same as those obtained in the presence of apyrase only (Fig. 6D). Thus, $\mathrm{P} 2 \mathrm{Y}_{1}$ receptors heterologously expressed in PC12 cells are spontaneously activated to an extent that renders further activation by either exogenously added or endogenously released nucleotides virtually impossible.

\section{Activation of heterologously expressed} $\mathrm{P}_{2} \mathrm{Y}_{1}$ receptors by added nucleotides

From the data presented above it was not possible to estimate at which nucleotide concentrations the $\mathrm{P} 2 \mathrm{Y}_{1}-\mathrm{GFP}$ receptors were activated when expressed in $\mathrm{PC} 12$ cells. To be able to do so, we searched for a measure of receptor activation that could be determined in the absence of released nucleotides. Single PC12 cells can be investigated by electrophysiological recording techniques under continuous superfusion to remove released nucleotides (Vartian and Boehm, 2001). $\mathrm{P}_{2} \mathrm{Y}_{1}$ receptors, when expressed in rat superior cervical ganglion neurons, mediate an inhibition of $K_{\mathrm{M}}$ channels in the presence of nanomolar ADP concentrations (Brown et al., 2000). We therefore hypothesized that this effect might also be seen in PC12 cells and determined $I_{\mathrm{M}}$ under continuous superfusion. In wild-type PC12 cells, ADP failed to cause significant changes in $\mathrm{IP}_{1}$ accumulation (Fig. $1 \mathrm{~B}$ ) and left $I_{\mathrm{M}}$ amplitudes unchanged (Fig. 7A). In PC12-P2 $\mathrm{Y}_{1}$ cells, however, ADP reduced $I_{M}$ in a concentration-dependent manner. This effect was half-maximal at $1.9 \pm 0.9 \mu \mathrm{M} \mathrm{ADP}$ (Fig. $7 B$ ). Thus, in the absence of endogenously released nucleotides, the $\mathrm{P}_{2} \mathrm{Y}_{1}-\mathrm{GFP}$ receptor expressed in PC12 cells is activated by low micromolar ADP concentrations.

\section{Discussion}

P2X receptors mediate neurotransmission when ATP is released by presynaptic action potentials (Robertson et al., 2001). In contrast, the mechanisms of activation and the functions of neuronal P2Y receptors are essentially unknown (Boehm, 2003). When $\mathrm{P} 2 \mathrm{Y}$ receptors are heterologously expressed in neurons, their activation leads to an inhibition of $K_{\mathrm{M}}$ and voltage-gated $\mathrm{Ca}^{2+}$ channels (Simon et al., 2002; Filippov et al., 2003). Evidence has been presented that depolarization of chromaffin cells leads to an autocrine-paracrine inhibition of $\mathrm{Ca}^{2+}$ channels via opioid and P2Y receptors (Currie and Fox, 1996). In non-neural cells, in contrast, the autocrine-paracrine activation of $\mathrm{P} 2 \mathrm{Y}$ receptors does not require depolarizing stimuli, and a simple exchange of culture media was found sufficient (Lazarowski et al., 2000; Ostrom et al., 2000). By using PC12 cells, the present results reveal that neuronal P2Y receptors are differentially activated by spontaneous and depolarization-evoked nucleotide release.

The accumulation of IPs and the inhibition of cAMP synthesis 
A
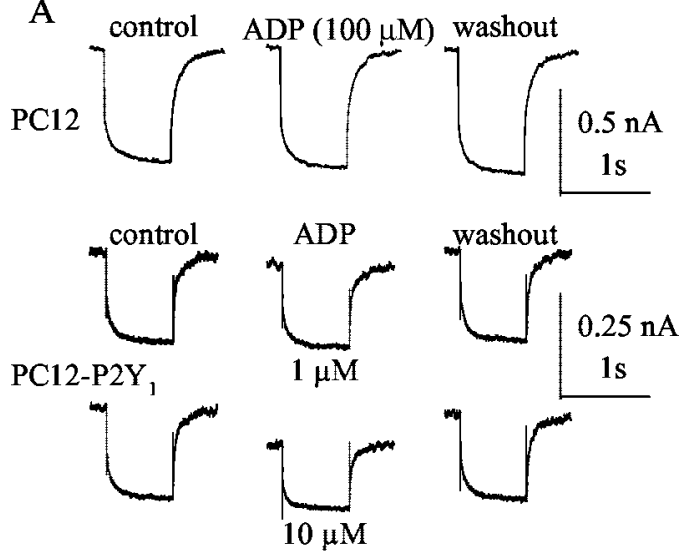

B

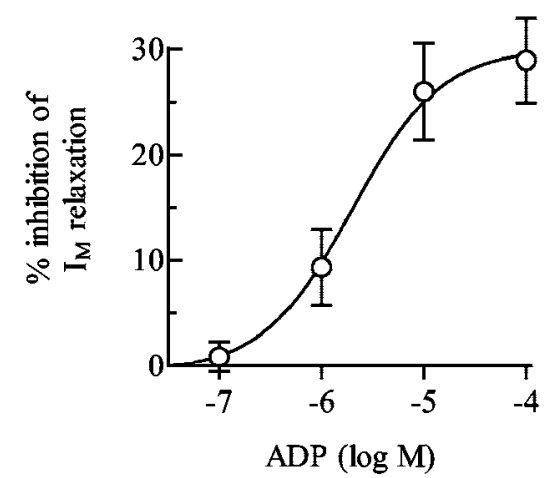

Figure 7. Inhibition of $I_{M}$ in $P 2 Y_{1}$ receptor expressing cells. $A, I_{M}$ was measured by the amphotericin B-perforated patch technique in a wild-type $\mathrm{PC} 12$ cell and in a PC12 cell stably expressing $P 2 Y_{1}$ receptors $\left(P C 12-P 2 Y_{1}\right)$. The current traces shown were obtained by clamping the cell at $-30 \mathrm{mV}$ and by applying 1 sec hyperpolarizing voltage steps to $-55 \mathrm{mV}$; the recordings were performed before (control), during, and after (washout) the application of the indicated concentrations of ADP. B, Four to six PC12-P2Y cells were exposed to the indicated concentrations of ADP, and the graph shows the concentration dependence of the inhibition of $I_{M}$ relaxation amplitudes, determined as shown in $A$.

in the presence of added nucleotides revealed that PC12 cells express two types of functional $\mathrm{P} 2 \mathrm{Y}$ receptors. The one coupled to IP synthesis is a $\mathrm{P} 2 \mathrm{Y}_{2}$ receptor as revealed by the following results: (1) it was equipotently activated by ATP and UTP and thus could be $\mathrm{P}_{2} \mathrm{Y}_{2}$ or $\mathrm{P}_{2} \mathrm{Y}_{4}$ (Kennedy et al., 2000); (2) $\mathrm{P} 2 \mathrm{Y}_{2}$ receptors are expressed at higher levels than $\mathrm{P}_{2} \mathrm{Y}_{4}$; $(3)$ the receptor was blocked by suramin but not by PPADS, and the reverse is true for $\mathrm{P}_{2} \mathrm{Y}_{4}$ (Bogdanov et al., 1998; Suarez-Huerta et al., 2001); (4) differentiation of PC12 cells reduced the expression of $\mathrm{P}_{2} \mathrm{Y}_{2}$ and diminished the IP synthesis in response to UTP. The reduction of CAMP, in contrast, is induced by ADP and ATP, but not UDP or $\mathrm{UTP}$, and is antagonized by the $\mathrm{P} 2 \mathrm{Y}_{12}$ antagonists $2 \mathrm{MeSAMP}$ and AR-C69931MX (Unterberger et al., 2002; Kubista et al., 2003), thus indicating a role of this latter receptor.

Degradation of nucleotides by apyrase did not alter IP accumulation in the absence of added nucleotides but enhanced the cAMP synthesis triggered by $\mathrm{A}_{2 \mathrm{~A}}$ receptor activation. Thus, $\mathrm{P} 2 \mathrm{Y}_{12}$ but not $\mathrm{P}_{2} \mathrm{Y}_{2}$ receptors were activated spontaneously. Depolarization of PC12 cells further decreased the cAMP synthesis and increased the IP accumulation. Both effects were abolished by apyrase and by the blockade of voltage-gated $\mathrm{Ca}^{2+}$ channels by $\mathrm{Cd}^{2+}$. Hence, both types of $\mathrm{P} 2 \mathrm{Y}$ receptors expressed in PC12 cells can be activated by depolarization-evoked nucleotide release.

One reason for the differential sensitivities for endogenously released nucleotides could be differences in agonist potencies of nucleotides at the receptors involved; however, overexpression of $\mathrm{P}_{2} \mathrm{Y}_{2}$ receptors did not allow for spontaneous receptor activation, although the potencies and efficacies of added nucleotides to induce IP synthesis were increased. In contrast, the heterologous expression of $\mathrm{P} 2 \mathrm{Y}_{1}$ receptors led to huge increases in spontaneous IP accumulation, which was hardly enhanced by added nucleotides or depolarization of the cells, but mostly reduced by apyrase or a $\mathrm{P}_{2} \mathrm{Y}_{1}$ receptor antagonist. Nevertheless, these $\mathrm{P} 2 \mathrm{Y}_{1}$ receptors could be activated by adding ADP when released nucleotides were removed by continuous superfusion. Furthermore, similar concentrations of added nucleotides were required to cause halfmaximal activation of overexpressed $\mathrm{P}_{2} \mathrm{Y}_{2}$ receptors $(1.4 \mu \mathrm{M}$ ATP) and heterologously expressed $\mathrm{P}_{2} \mathrm{Y}_{1}$ receptors $(1.9 \mu \mathrm{M}$ ADP). Thus, there were no significant differences in the potencies of agonistic nucleotides at these two receptors expressed in PC12 cells. One major difference between $\mathrm{P}_{2} \mathrm{Y}_{1}$ and $\mathrm{P} 2 \mathrm{Y}_{2}$ receptors is their distinct nucleotide sensitivity: $\mathrm{P}_{2} \mathrm{Y}_{1}$ but not $\mathrm{P} 2 \mathrm{Y}_{2}$ receptors are activated not only by ATP but also by ADP (Ralevic and Burnstock, 1998). $\mathrm{P}_{12} \mathrm{Y}_{12}$ receptors also accept ADP as an agonist (Hollopeter et al., 2001). Hence, the propensity of recombinant $\mathrm{P} 2 \mathrm{Y}_{1}$ and native $\mathrm{P} 2 \mathrm{Y}_{12}$ receptors to be activated by spontaneous nucleotide release is related to their sensitivity for nucleoside diphosphates rather than to higher receptor densities or higher nucleotide potencies.

This leads to the question of species and quantities of nucleotides released from PC12 cells. Large and small dense-core vesicles contain millimolar concentrations of adenine nucleotides. Among these, one can find ATP, ADP, and AMP at a 1:0.14:0.04 ratio (Zimmermann, 1994). Therefore, the main nucleotide released from PC12 cells is ATP. We did not try to determine concentrations of ATP or ADP in the culture medium, because concentrations of nucleotides in solutions in which cells under investigation are incubated do not reflect the concentrations close to the plasma membrane, where receptors are activated (Beigi et al., 1999). Nevertheless, our results with endogenous and overexpressed $\mathrm{P} 2 \mathrm{Y}_{2}$ receptors provide an indication of the periplasmalemmal ATP concentration yielded by $\mathrm{K}^{+}$depolarization: $100 \mathrm{mM} \mathrm{K}^{+}$stimulated IP synthesis somewhat less than 10 $\mu \mathrm{M}$ but definitely more than $1 \mu \mathrm{M}$ ATP. Similarly, the $\mathrm{K}^{+}$depolarization reduced cAMP accumulation to almost the same extent as $10 \mu \mathrm{M} \mathrm{ADP}$, which is equipotent and equi-effective to ATP in inhibiting adenylyl cyclase in PC12 cells (Unterberger et al., 2002). Therefore, the concentration of endogenous ATP surrounding PC12 cells during $\mathrm{K}^{+}$depolarization must be in the low micromolar range. This estimate is similar to the concentration of ATP surrounding platelets when stimulated by thrombin, which lies between 5 and $20 \mu \mathrm{M}$ (Beigi et al., 1999). Because neither endogenous nor overexpressed $\mathrm{P}_{2} \mathrm{Y}_{2}$ receptors were activated under basal conditions, the periplasmalemmal ATP concentration in the absence of depolarizing stimuli must be below the $100 \mathrm{nM}$ of added ATP that was required to cause minimal stimulation of IP synthesis (Fig. $5 B$ ).

In contrast to $\mathrm{P}_{2} \mathrm{Y}_{2}$ receptors, endogenous $\mathrm{P} 2 \mathrm{Y}_{12}$ and recombinant $\mathrm{P} 2 \mathrm{Y}_{1}$ receptors were activated spontaneously. At rat $\mathrm{P} 2 \mathrm{Y}_{12}$ receptors, ADP is 10-fold more potent than ATP (Simon et al., 2002), and at the rat $P 2 Y_{1}-$ GFP fusion protein, ADP is 100 -fold more potent than ATP (Vohringer et al., 2000). Thus, the spontaneous activation of $\mathrm{P} 2 \mathrm{Y}_{12}$ and $\mathrm{P} 2 \mathrm{Y}_{1}$ receptors was mediated by $\mathrm{ADP}$ rather than ATP. The spontaneous activation of $\mathrm{P} 2 \mathrm{Y}_{12}$ receptors limited the stimulation of cAMP synthesis by the $A_{2 A}$ receptor agonist CGS 21680. In the absence of added nucleotides, CGS 21680 enhanced cAMP accumulation 20-fold; in the pres- 
ence of apyrase or the $\mathrm{P} 2 \mathrm{Y}_{12}$ antagonist $2 \mathrm{MeSAMP}$, however, this stimulation was increased to $\geq 50$-fold, and added ADP reduced this stimulation down to 5 -fold over basal. Thus, the value obtained in the absence of agonists and antagonists was close to the arithmetic mean of these two extremes, which indicates that the receptors were approximately half-activated. In rat endothelial cells, inhibition of adenylyl cyclase via $\mathrm{P}_{2} \mathrm{Y}_{12}$ receptors is halfmaximal at $3 \mu \mathrm{M}$ ADP (Simon et al., 2002). P2 $\mathrm{Y}_{1}-\mathrm{GFP}$ receptors were completely activated under conditions of spontaneous nucleotide release. When released nucleotides were removed by superfusion, the $\mathrm{P} 2 \mathrm{Y}_{1}-\mathrm{GFP}$ receptor was activated at 1-10 $\mu \mathrm{M}$ ADP, as determined by the inhibition of $I_{\mathrm{M}}$. In HEK 293 cells expressing the $\mathrm{P} 2 \mathrm{Y}_{1}-\mathrm{GFP}$ receptor, $\sim 1 \mu \mathrm{M}$ ADP causes maximal IP accumulation (Vohringer et al., 2000). Taken together, the above considerations suggest that the basal periplasmalemmal ADP concentration in PC12 cell cultures was in the range of $1-10 \mu \mathrm{M}$.

These data indicate that in PC12 cell cultures, ADP concentrations are higher than those of ATP, although more ATP is released (Zimmermann, 1994). The explanation for this discrepancy is the fact that PC12 cells express ectonucleotidases that degrade ATP four times more rapidly than ADP. As a consequence, extracellular ADP accumulates (Vollmayer et al., 2001), and this is the basis for the spontaneous activation of nucleoside diphosphate-sensitive $\left(\mathrm{P}_{2} \mathrm{Y}_{12}\right.$ and $\left.\mathrm{P}_{2} \mathrm{Y}_{1}\right)$ receptors and the lack of spontaneous activity of $\left(\mathrm{P}_{2} \mathrm{Y}_{2}\right)$ receptors that are sensitive only to nucleoside triphosphates. Nevertheless, these latter receptors become activated when the release of ATP is increased by $\mathrm{K}^{+}$depolarization and exceeds its degradation to ADP. Thus, the endowment of PC12 cells with ectonucleotidases and P2Y receptors provides specific sensors for spontaneous and stimulationevoked vesicle exocytosis. Accordingly, in PC12 cells, levels of second messengers linked to $\mathrm{P} 2 \mathrm{Y}$ receptors will correlate with the electrical activity of the cells.

The present as well as previous results show that in a given cell, the autocrine-paracrine regulation via released nucleotides depends on the presence of both $\mathrm{P} 2 \mathrm{Y}$ receptors and nucleotidases. In hepatoma cells (Junankar et al., 2002), for example, released ATP is degraded to ADP to stimulate $\mathrm{P}_{2} \mathrm{Y}_{1}$ receptors. In epithelial (Torres et al., 2002) and osteoblastic (You et al., 2002) cells, in contrast, released ATP itself activates $\mathrm{P}_{2} \mathrm{Y}_{11}$ and $\mathrm{P} 2 \mathrm{Y}_{2}$ receptors, respectively. In PC12 cells, both types of autocrine-paracrine regulation occur under resting conditions and during depolarization and involve $\mathrm{P}_{2} \mathrm{Y}_{12}$ and $\mathrm{P}_{2} \mathrm{Y}_{2}$ receptors, respectively. In sympathetic neurons that are ontogenetically related to PC12 cells, nucleotide release occurs at a low rate that is mostly enhanced by depolarization (von Kugelgen et al., 1994). Together with nucleotides, sympathetic neurons release soluble nucleotidases that degrade ATP twice as rapidly as ADP (Mihaylova-Todorova et al., 2002), and therefore ADP accumulates rather than ATP (Todorov et al., 1997). Because sympathetic neurons, like PC12 cells, express several P2Y receptors linked to different signaling cascades (Fig. 2C), the phenomena described above for PC12 cells can be expected to apply to the sympathetic and possibly to other pathways within the nervous system.

\section{References}

Arslan G, Filipeanu CM, Irenius E, Kull B, Clementi E, Allgaier C, Erlinge D, Fredholm BB (2000) P2Y receptors contribute to ATP-induced increases in intracellular calcium in differentiated but not undifferentiated PC12 cells. Neuropharmacology 39:482-496.

Beigi R, Kobatake E, Aizawa M, Dubyak GR (1999) Detection of local ATP release from activated platelets using cell surface-attached firefly luciferase. Am J Physiol 276:C267-C278.
Boehm S (1999) ATP stimulates sympathetic transmitter release via presynaptic P2X purinoceptors. J Neurosci 19:737-746.

Boehm S (2003) P2Ys go neuronal: modulation of $\mathrm{Ca}^{2+}$ and $\mathrm{K}^{+}$channels by recombinant receptors. Br J Pharmacol 138:1-3.

Bofill-Cardona E, Vartian N, NanoffC, Freissmuth M, Boehm S (2000) Two different signaling mechanisms involved in the excitation of rat sympathetic neurons by uridine nucleotides. Mol Pharmacol 57:1165-1172.

Bogdanov YD, Wildman SS, Clements MP, King BF, Burnstock G (1998) Molecular cloning and characterization of rat P2Y4 nucleotide receptor. Br J Pharmacol 124:428-430.

Brown DA, Filippov AK, Barnard EA (2000) Inhibition of potassium and calcium currents in neurones by molecularly-defined P2Y receptors. J Auton Nerv Syst 81:31-36.

Communi D, Pirotton S, Parmentier M, Boeynaems JM (1995) Cloning and functional expression of a human uridine nucleotide receptor. J Biol Chem 270:30849-30852.

Communi D, Govaerts C, Parmentier M, Boeynaems JM (1997) Cloning of a human purinergic receptor coupled to phospholipase C and adenylyl cyclase. J Biol Chem 51:31969-31973.

Communi D, Gonzales NS, Detheux M, Brezillon S, Lannoy V, Parmentier M, Boeynaems JM (2001) Identification of a novel human ADP receptor coupled to Gi. J Biol Chem 276:41479-41485.

Currie KPM, Fox AP (1996) ATP serves as a negative feedback inhibitor of voltage-gated $\mathrm{Ca}^{2+}$ channel currents in bovine adrenal chromaffin cells. Neuron 16:1027-1036.

De Lean A, Munson PJ, Rodbard D (1978) Simultaneous analysis of families of sigmoidal curves: application to bioassay, radioligand assay, and physiological dose-response curves. Am J Physiol 235:97-102.

Filippov AK, Simon J, Barnard EA, Brown DA (2003) Coupling of the nucleotide $\mathrm{P}_{2} \mathrm{Y}_{4}$ receptor to neuronal ion channels. Br J Pharmacol 138:400-406.

Fisher RJ, Burgoyne RD (1999) The effect of transfection with Botukinum neurotoxin $\mathrm{C} 1$ light chain on exocytosis measured in cell populations and by single-cell amperometry in PC12 cells. Pflügers Arch 437:754-762.

Gerasimovskaya EV, Ahmad S, White CW, Jones PL, Carpenter TC, Stenmark KR (2002) Extracellular ATP is an autocrine-paracrine regulator of hypoxia-induced adventitial fibroblast growth. J Biol Chem 277:44638-44650.

Greene LA, Tischler AS (1976) Establishment of a noradrenergic clonal line of rat adrenal pheochromocytoma cells which respond to nerve growth factor. Proc Natl Acad Sci USA 73:2424-2428.

Hollopeter G, Jantzen HM, Vincent D, Li G, England L, Ramakrishnan V, Yang RB, Nurden A, Julius D, Conley PB (2001) Identification of the plateleted ADP receptor targeted by antithrombotic drugs. Nature 409:202-207.

Junankar PR, Karjalainen A, Kirk K (2002) The role of P2Y1 purinergic receptors and cytosolic $\mathrm{Ca}^{2+}$ in hypotonically activated osmolyte efflux from a rat hepatoma cell line. J Biol Chem 277:40324-40334.

Kennedy C, Qi AD, Herold CL, Harden TK, Nicholas RA (2000) ATP, an agonist at the rat $\mathrm{P} 2 \mathrm{Y}(4)$ receptor, is an antagonist at the human $\mathrm{P}_{2} \mathrm{Y}_{4}$ receptor. Mol Pharmacol 57:926-931.

Kubista H, Lechner SG, Wolf AM, Boehm S (2003) Attenuation of the P2Y receptor-mediated control of neuronal $\mathrm{Ca}^{2+}$ channels in PC12 cell by antithrombotic drugs. Br J Pharmacol 138:343-350.

Lazarowski ER, Boucher RC, Harden TK (2000) Constitutive release of ATP and evidence for major contribution of ecto-nucleotide pyrophosphatase and nucleoside diphosphokinase to extracellular nucleotide concentrations. J Biol Chem 275:31061-31068.

Lustig KD, Shiau AK, Brake AJ, Julius D (1993) Expression cloning of an ATP receptor from mouse neuroblastoma cells. Proc Natl Acad Sci USA 90:5113-5117.

Matthews G (1996) Transmitter release. Annu Rev Neurosci 19:219-233.

Mihaylova-Todorova ST, Todorov LD, Westfall DP (2002) Enzyme kinetics and pharmacological characterization of nucleotidases released from the guinea pig isolated vas deferens during nerve stimulation: evidence for a soluble ecto-nucleoside triphosphate diphosphohydrolase-like ATPase and a soluble ecto-5' ${ }^{\prime}$-nucleotidase-like AMPase. J Pharmacol Exp Ther 302:992-1001.

Murrin JA, Boarder MR (1992) Neuronal nucleotide receptor linked to phospholipase C and phospholipase D? Stimulation of PC12 cells by ATP analogues and UTP. Mol Pharmacol 41:561-568.

Nandanan E, Camaioni E, Jang SY, Kim YC, Cristalli G, Herdewijn P, Secrist 
JA, Tiwari KN, Mohanram A, Harden TK, Boyer JL, Jacobson KA (1999) Structure-activity relationships of biphosphate nucleotide derivatives as $\mathrm{P}_{2} \mathrm{Y}_{1}$ receptor antagonists and partial agonists. J Med Chem 42:1625-1638.

Nicholas RA, Watt WC, Lazarowski ER, Li Q, Harden TK (1996) Uridine nucleotide selectivity of three phospholipase C-activating P2 receptors: identification of a UDP-selective, a UTP-selective, and an ATP- and UTPspecific receptor. Mol Pharmacol 50:224-229.

Ostrom RS, Gregorian C, Insel PA (2000) Cellular release of and response to ATP as key determinants of the set-point of signal transduction pathways. J Biol Chem 275:11735-11739.

Phiel CJ, Klein PS (2001) Molecular targets of lithium action. Annu Rev Pharmacol Toxicol 41:789-813.

Ralevic V, Burnstock G (1998) Receptors for purines and pyrimidines. Pharmacol Rev 50:413-492.

Robertson SJ, Ennion SJ, Evans RJ, Edwards FA (2001) Synaptic P2X receptors. Curr Opin Neurobiol 11:378-386.

Schlosser SF, Burgstahler AD, Nathanson MH (1996) Isolated rat hepatocytes can signal to other hepatocytes and bile duct cells by release of nucleotides. Proc Natl Acad Sci USA 93:9948-9953.

Scholze T, Moskvina E, Mayer M, Just H, Kubista H, Boehm S (2002) Sympathoexcitation by bradykinin involves $\mathrm{Ca}^{2+}$-independent protein kinase C. J Neurosci 22:5823-5832.

Schwiebert EM, Wallace DP, Braunstein GM, King SR, Peti-Peterdi J, Hanaoka K, Guggino WB, Guay-Woodford LM, Bell BD, Suillivan LP, Grantham JJ, Taylor AL (2002) Autocrine extracellular purinergic signaling in epithelial cells derived from polycystic kidneys. Am J Physiol 282:F763-F775.

Simon J, Filippov AK, Goransson S, Wong YH, Frelin C, Michel AD, Brown DA, Barnard EA (2002) Characterization and channel coupling of the P2 $\mathrm{Y}_{12}$ nucleotide receptor of brain capillary endothelial cells. J Biol Chem 277:31390-31400.

Suarez-Huerta N, Pouillon V, Boeynaems JM, Robaye B (2001) Molecular cloning and characterization of the mouse P2Y4 receptor. Eur J Pharmacol 416:197-202.
Tokuyama Y, Hara M, Jones EMC, Fan Z, Bell GI (1995) Cloning of rat and mouse P2Y purinoceptors. Biochem Biophys Res Commun 211:211-218.

Todorov LD, Mihaylova-Todorova S, Westfall TD, Sneddon P, Kennedy C Bjur RA, Westfall DP (1997) Neuronal release of soluble nucleotidases and their role in neurotransmitter inactivation. Nature 387:76-79.

Torres B, Zambon AC, Insel PA (2002) P2Y $\mathrm{Y}_{11}$ receptors activate adenylyl cyclase and contribute to nucleotide-promoted cAMP formation in MDCK-D cells. J Biol Chem 277:7761-7765.

Unterberger U, Moskvina E, Scholze T, Freissmuth M, Boehm S (2002) Inhibition of adenylyl cyclase by neuronal P2Y receptors. Br J Pharmacol 135:673-684.

Vartian N, Boehms S (2001) P2Y receptor-mediated inhibition of voltageactivated $\mathrm{Ca}^{2+}$ currents in PC12 cells. Eur J Neurosci 13:899-908.

Vartian N, Moskvina E, Scholze T, Unterberger U, Allgaier C, Boehm S (2001) UTP evokes noradrenaline release from rat sympathetic neurons by activation of protein kinase C. J Neurochem 77:876-885.

Vohringer C, Schafer R, Reiser G (2000) A chimeric rat brain P2Y1 receptor tagged with green fluorescent protein: high affinity ligand recognition of adenosine diphosphates and triphosphates and selectivity identical to that of the wild-type receptor. Biochem Pharmacol 59:791-800.

Vollmayer P, Koch M, Braun N, Heine P, Servos J, Israr E, Kegel B, Zimmermann H (2001) Multiple ectonucleotidases in PC12 cells: identification and cellular distribution after heterologous expression. J Neurochem 78:1019-1028

von Kugelgen I, Allgaier C, Schobert A, Starke K (1994) Co-release of noradrenaline and ATP from cultured sympathetic neurons. Neuroscience 61:199-202.

Wang Y, Roman R, Lidofsky SD, Fitz JG (1996) Autocrine signaling through ATP release represents a novel mechanism for cell volume regulation. Proc Natl Acad Sci USA 93:12020-12025.

You J, Jacobs CR, Steinberg TH, Donahue HJ (2002) P2Y purinoceptors are responsible for oscillatory fluid flow-induced intracellular $\mathrm{Ca}^{2+}$ mobilization in osteoblastic cells. J Biol Chem 277:48724-48729.

Zimmermann H (1994) Signaling via ATP in the nervous system. Trends Neurosci 17:420-426. 